\title{
The distribution and characterization of HNK-1 antigens in the developing avian heart
}

\author{
Theo M. Luider ${ }^{1}$, Nathalie Bravenboer ${ }^{1}$, Carel Meijers ${ }^{1}$, Arthur W.M. van der Kamp ${ }^{2}$, Dick Tibboel $^{1}$, \\ Robert E. Poelmann ${ }^{3}$ \\ ${ }^{1}$ Department of Paediatric Surgery, Sophia Children Hospital, Erasmus University, P.O. Box 1738, NL-3000 DR Rotterdam, \\ The Netherlands \\ ${ }^{2}$ MGC-Department of Cell Biology and Genetics, Erasmus University, P.O. Box 1738, NL-3000 DR Rotterdam, The Netherlands \\ ${ }^{3}$ Department of Anatomy and Embryology, State University of Leiden, P.O. Box 9602, NL-2300 Leiden, The Netherlands
}

Accepted: 28 May 1993

\begin{abstract}
The heart originates from splanchnic mesoderm and to a lesser extent from neural crest cells. The HNK-1 monoclonal antibody is a marker for early migrating neural crest cells, but reacts also with structures which are not derived from the neural crest. We investigated whether heart structures are HNK-1 positive before neural crest cells colonize these target tissues. To that end, we determined the HNK-1 antigen expression in the developing avian heart on immunohistochemical sections and on Western blots. The HNK-1 immunoreactivity in the developing chick heart is compared with data from literature on the localization of neural crest cells in chick/quail chimeras. Structures with neural crest contribution, including parts of the early outflow tract and the related endocardial cushions, the primordia of the semilunar valve leaflets and the aorticopulmonary septum were HNK-1 positive. Furthermore, other structures were HNK-1 positive, such as the atrioventricular cushions, the wall of the sinus venosus at stage $\mathrm{HH} 15$ through 21, parts of the endocardium at E3, parts of the myocardium at E6, and the extracellular matrix in the myocardial base of the semilunar valves at E14. HNK-1 expression was particularly observed in morphologically dynamic regions such as the developing valves, the outflow tract cushion, the developing conduction system and the autonomic nervous system of the heart. We observed that atrioventricular endocardial cushions are HNK-1 positive. We conclude that: a HNK-1 immunoreactivity does not always coincide with the presence of neural crest cells or their derivatives; (2) the outflow tract cushions and atrioventricular endocardial cushions are HNK-1 positive before neural crest cells are expected (stage HH 19) to enter the endocardial cushions of the outflow tract; (3) the observed spatio-temporal HNK-1 patterns observed in the developing heart correspond with various HNK-1 antigens. Apart from a constant pattern of HNK-1 antigens during development, stage-dependent HNK-1 antigens were also found.
\end{abstract}

Key words: HNK-1 - Neural crest - Heart development

Correspondence to: T.M. Luider

\section{Introduction}

The heart is one of the first functioning organs in vertebrate embryos. It develops from two plates of splanchnic mesoderm, which fuse to form a single tubular structure, composed of endocardium surrounded by myocardium separated by the cardiac jelly (for review see de Ruiter et al. 1992).

The tubular structure develops into a multi-chambered, specialized organ. This development is initiated by a regionally specific transformation of the endocardial cells into migrating, and proliferating mesenchymal cells (reviewed in Markwald et al. 1990). These mesenchymal cells colonize the cardiac jelly in the outflow tract and at the atrioventricular junction to form both the outflow tract and atrioventricular endocardial cushions (Markwald et al. 1977). These transient endocardial cushions are involved in the formation of the connective tissue of the interventricular septum, the semilunar and atrioventricular valves of the heart. Although the heart tissue originates mainly from mesoderm, the neuroectoderm is also involved. The neural crest, a transient structure which arises on the dorsal margin of the neural folds during neurulation, provides these neuroectodermal cells (Kirby et al. 1983, 1989; Phillips et al. 1987; Noden 1991). Neural crest cells from the region between the mid-otic placode and the caudal limit of somite 3 migrate into the pharyngeal arches 3,4 , and 6 , where they provide a mesenchymal matrix around the aortic arch arteries (LeLièvre and LeDouarin 1975). Neural crest cells migrate first of all and essentially into the wall of the aortic sac. After having contributed to the formation of the aorticopulmonary septum, some of them reach the outflow tract (conotruncus). They contribute also to the parasympathetic postganglionic neurons and supportive cells of the cardiac ganglia. Although the contribution of cardiac neural crest cells in the total number of cardiac cells is small, the ablation of the cardiac neural crest results in severe structural abnormalities of the outflow tract and the aortic arch arteries, resembling certain anomalies seen in human patients (Kirby and Waldo 1990). 
With regard to the origin of the cardiac conducting system, two possibilities are described in the literature. The majority of investigators propose the myocardium as the origin for the conducting system (Wenink 1976; Marino et al. 1979; Viragh and Challice 1983; Davies et al. 1983; Wenink and Gittenberger-de Groot 1985; Argüello et al. 1988), while some propose a neural crest origin (Gorza et al. 1988).

The homing or migration of the neural crest cells has been studied by different experimental manipulations: perturbation with the monoclonal antibody HNK-1 (Bronner-Fraser 1987), transplantations of quail tissue into chick hosts (LeDouarin 1982), ablation (Bockman et al. 1987; Kirby and Waldo 1990), or administration of teratogens (Sulik et al. 1988). Experimental manipulations of the cardiac neural crest using these techniques can result in cardiac anomalies. For example, ablation of the cardiac neural crest results in outflow tract anomalies, with persistent truncus arteriosus as the most severe form (Bockman et al. 1987; Kirby and Waldo 1990).

Premigratory and migrating neural crest cells can be visualized by the monoclonal antibody HNK-1. Although other structures, e.g. the notochord (Canning and Stern 1988), are also HNK-1 positive, it is accepted that the HNK-1 antibody can be used as a marker for chick neural crest cells (Vincent et al. 1983; Tucker et al. 1984, 1986). It has to be kept in mind that the HNK-1 epitope has been found on a large population of molecules involved in cell adhesion, substrate adhesion and extracellular matrix interactions (Kruse et al. 1984; Faissner 1987; Pesheva et al. 1987; Hoffman and Edelman 1987). It has been suggested that the HNK-1 epitope itself is involved in cell-cell or cell-matrix adhesion (Keilhauer et al. 1985; Bronner-Fraser 1987; Künemund et al. 1988).

Previously we have reported that mesenchymal cells in the hindgut express specific HNK-1 antigens before neural crest cells colonize this tissue. We observed that this expression correlates with the neural crest cell colonization of the gut (Luider et al. 1992). In the present study we describe the expression of HNK-1 antigens in the developing heart, and investigate whether HNK-1 antigens are already present on the sites where cardiac neural crest cells are expected to colonize the heart. For this purpose we determined the HNK-1 expression, both on tissue sections and on immunoblots of the developing heart before and after neural crest cell homing. We compared the localization of HNK-1 expression with the presence of neural crest cells as described in chimera experiments with quail neural crest cells (Kirby 1989; Sumida et al. 1989; Noden 1991).

\section{Materials and methods}

Embryos. Fertilized eggs of Gallus gallus domesticus were obtained from a local supplier and incubated in a forced-draught incubator at $37^{\circ} \mathrm{C}$ and $80 \%$ humidity. Embryos were staged according to Hamburger and Hamilton (1951). This notation was used until stage HH 21, which is equivalent to day 3 to day 4 of development. In older incubation stages the E notation was used (day of develop- ment). Each $\mathrm{E}$ number covers a number of $\mathrm{HH}$ stages, i.e. $\mathrm{E} 2=$ stage $\mathrm{HH} 12-15 ; \mathrm{E} 3=$ stage $\mathrm{HH} 16-20 ; \mathrm{E} 4=$ stage $\mathrm{HH} 21-23 ; \mathrm{E} 5=$ stage $\mathrm{HH} 24-26 ; \mathrm{E} 6=$ stage $\mathrm{HH} 27-28 ; \mathrm{E} 8=$ stage $\mathrm{HH} 31-33 ; \mathrm{E} 9=$ stage $\mathrm{HH} 34-35 ; \mathrm{E} 10=$ stage $\mathrm{HH} 36 ; \mathrm{E} 14=$ stage HH 40.

Hybridoma cell culture. The HNK-1 hybridoma was purchased from the American Tissue Type Culture Collection (TIB200) (Abo and Balch 1981). Cells were grown in RPMI medium (Life Technologies, Breda, the Netherlands) supplemented with $10 \%$ fetal calf serum (Sanbio, Uden, the Netherlands), penicillin $75 \mathrm{mg} / \mathrm{ml}$, streptomycin $125 \mathrm{mg} / \mathrm{ml}$ and glutamine $292 \mathrm{mg} / \mathrm{ml}$ (Life Technologies, Breda, the Netherlands). Conditioned media were harvested after 3 days of culture and spun at $1000 \mathrm{rev} / \mathrm{min}$ for $10 \mathrm{~min}$. Pellets were discarded and the supernatants stored at $-20^{\circ} \mathrm{C}$. The M1B4 monoclonal antibody, specific for tenascin (Chiquet and Fambrough 1984) was obtained from the Developmental Studies Hybridoma Bank, Iowa.

Immunohistochemistry. Serial sections were prepared from whole chick embryos at the stages HH15, HH17, HH19, HH21, E3, E4, and E6. Dissected hearts were used to study the developmental stages E5, E6, E8, E9, E10, and E14.

Tissues were fixed by immersion in $4 \%$ paraformaldehyde/PBS overnight. After dehydration, heart tissue was embedded in paraffin, cut in transverse or sagittal sections, and rehydrated. Sections were incubated in $1 \% \mathrm{H}_{2} \mathrm{O}_{2}$ /methanol to inhibit endogenous peroxidades. Both incubation with the HNK-1 antibody (undiluted) and the secondary antibody rabbit-anti-mouse immunoglobulin conjugated with peroxidase (Dako, Denmark), 100 times diluted, were performed for $1 \mathrm{~h}$ at room temperature. The tissue sections were stained with $1 \mathrm{mg} \mathrm{3,3-diaminobenzidine} \mathrm{and} 100 \mu \mathrm{l} 3.3 \%$ $\mathrm{H}_{2} \mathrm{O}_{2}$ in $5 \mathrm{ml} \mathrm{PBS} / 0.1 \%$ Tween 20 for $5 \mathrm{~min}$ at room temperature, and counterstained with haematoxylin (Mayer). Finally, the sections were photographed on Ektachrome 50 film with a Leitz microscope (Orthoplane).

Homogenization of tissues for protein analysis. Hearts from different developmental stages (E2; E4; E6; E8; E10; E12; E14) were pooled in $1 \mathrm{ml} 1 \%$ Triton $\mathrm{X}-114 / \mathrm{PBS}$, containing the following protease inhibitors: $1 \mathrm{mM}$ PMSF (Sigma) $2 \mu \mathrm{g} / \mathrm{ml}$ aprotinin (Sigma), $0.7 \mu \mathrm{g} /$ $\mathrm{ml}$ pepstatin (Sigma), $0.7 \mu \mathrm{g} / \mathrm{ml} 2,3$ dehydro-2-deoxy- $N$-acetyl-neuraminic acid (Sigma). The collected hearts were homogenized in a glass tube with a teflon pestle. Subsequently the homogenate was sonicated in a MSE 100 Watt ultrasonic disintegrator for $1 \mathrm{~min}$, amplitude $6-8 \mu \mathrm{m}$, and centrifuged for $2 \mathrm{~min}$ in an Eppendorf centrifuge. Protein content of pooled hearts was determined (BCA, Pierce): E2 (0.63 mg, $n=60) ; \mathrm{E} 4(1.1 \mathrm{mg}, n=29) ; \mathrm{E} 6$ $(5.5 \mathrm{mg}, n=19) ; \mathrm{E} 8(6.1 \mathrm{mg}, n=16) ; \mathrm{E} 10(6.7 \mathrm{mg}, n=8) ; \mathrm{E} 12$ (14.0 $\mathrm{mg}, n=8)$, and E14 (17 mg, $n=5)$. The supernatant was stored at $-20^{\circ} \mathrm{C}$.

Homogenization of tissues for plasma membrane analysis. Hearts at stage $\mathrm{E} 6(n=29)$, and $\mathrm{E} 9(n=19)$ were pooled in TSE buffer $\left(10 \mathrm{mM}\right.$ TRIS $/ \mathrm{HCl}, \mathrm{pH} 8.0,0.25 \mathrm{M}$ sucrose, $1 \mathrm{mM} \mathrm{EDTA}$ ) at $4^{\circ} \mathrm{C}$. Plasma membranes were obtained according to a modification of the protocol of Maeda and coworkers (1983). In brief, tissues were collected in TSE buffer at $4^{\circ} \mathrm{C}$ and homogenized in an Omni Mixer Homogenizer (Connecticut, USA) on ice for $1 \mathrm{~min}$ (level 10). The suspension was centrifuged for $5 \mathrm{~min}$ at $2000 \mathrm{rev} / \mathrm{min}$ in an Heraeus centrifuge. The supernatant was layered on a solution containing $41 \%$ sucrose, $10 \mathrm{mM}$ TRIS/ $\mathrm{HCl} \mathrm{pH} 8.0,1 \mathrm{mM}$ EDTA and centrifuged in a Beckman ultracentrifuge for $1 \mathrm{~h}$ at $24000 \mathrm{rev} / \mathrm{min}$ in a SW28 rotor. The interphase containing the plasma membranes was collected and diluted with TSE buffer and centrifuged again for $1 \mathrm{~h}$ at $24000 \mathrm{rev} / \mathrm{min}$ in a SW28 rotor. The pellet was resuspended in TSE buffer and stored at $-70^{\circ} \mathrm{C}$. Protein content was determined from each sample (E6:0.3 $\mathrm{mg} / \mathrm{ml} ; \mathrm{E} 9: 1.2 \mathrm{mg} / \mathrm{ml})$.

SDS Polyacrylamide-gel-electrophoresis. Protein samples were boiled in a buffer containing: $60 \mathrm{mM}$ TRIS-HCl, $\mathrm{pH} 6.8,10 \%$ glycerol, 2\% SDS, 5\% 2-mercaptoethanol and $0.001 \%$ bromophenol blue. After denaturation, $50 \mu \mathrm{g}$ protein was electrophoresed 

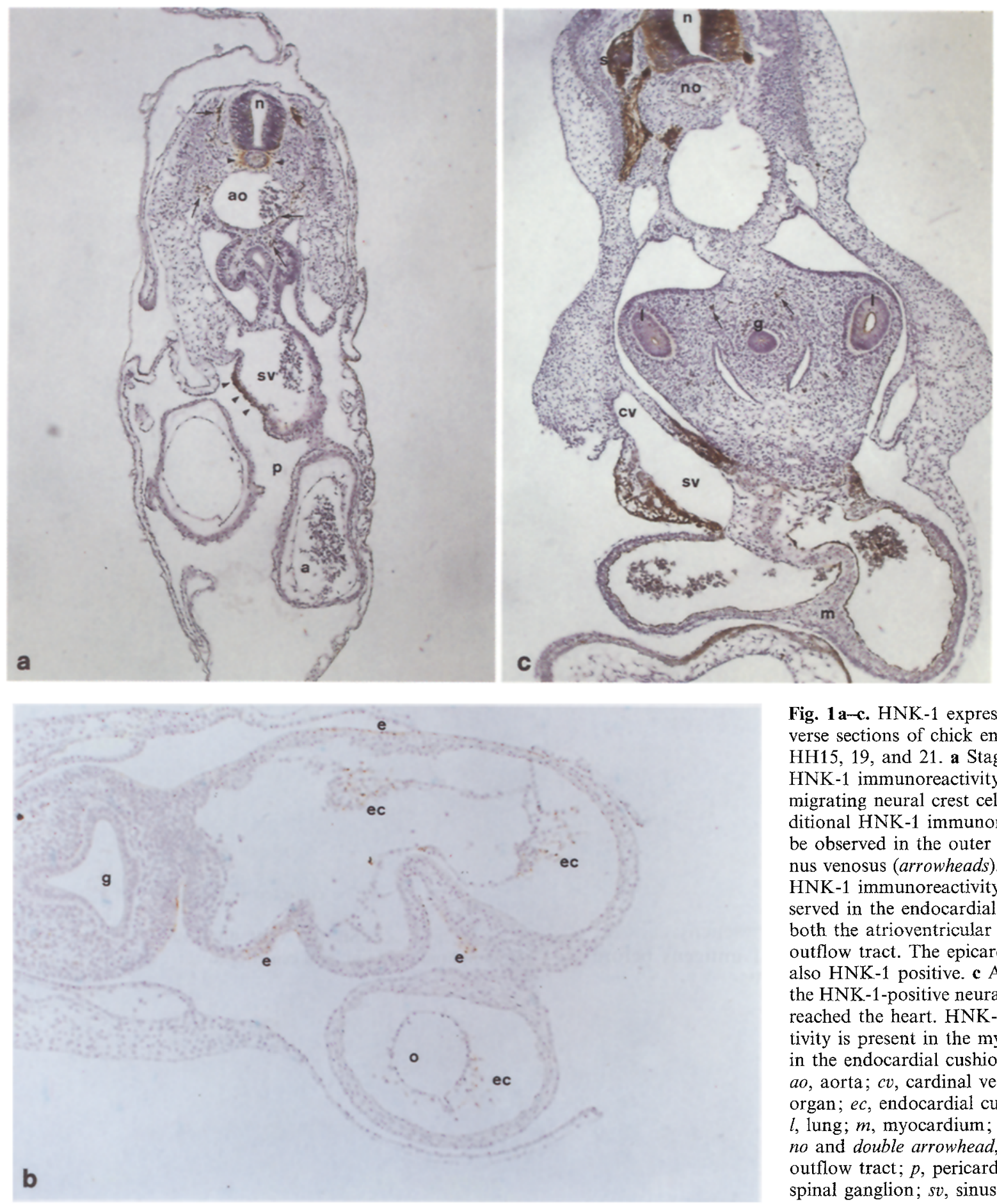

Fig. 1 a-c. HNK-1 expression in transverse sections of chick embryos of stages HH15, 19, and 21. a Stage HH15:

HNK-1 immunoreactivity is present in migrating neural crest cells (arrows). Additional HNK-1 immunoreactivity can be observed in the outer wall of the sinus venosus (arrowheads). b Stage HH19: HNK-1 immunoreactivity can be observed in the endocardial cushions of both the atrioventricular canal and the outflow tract. The epicardial organ is also HNK-1 positive. $c$ At stage $\mathrm{HH} 21$ the HNK-1-positive neural crest cells have reached the heart. HNK-1 immunoreactivity is present in the myocardium and in the endocardial cushions. $a$, Atrium; $a o$, aorta; $c v$, cardinal vein; $e$, epicardial organ; $e c$, endocardial cushion; $g$, gut; $l$, lung; $m$, myocardium; $n$, neural tube; no and double arrowhead, notochord; $o$, outflow tract; $p$, pericardial cavity; $s$, spinal ganglion; $s v$, sinus venosus

on $7.5 \%$ SDS polyacrylamide gels (SDS/PAA), prepared according to the description of the manufacturer (Biorad, Veenendaal, the Netherlands). High-molecular-weight protein standards were obtained from Life Technologies (Breda, the Netherlands).

Proteins were transferred from the SDS/PAA gel onto a $0.45-$ $\mu \mathrm{m}$ nitrocellulose SSBA 85 membrane (Schleicher and Schuell, Dassel, Germany) in a Biorad blot apparatus at $200 \mathrm{~mA}$ and $100 \mathrm{~V}$ for $90 \mathrm{~min}$ in a blotting buffer containing $20 \%(\mathrm{v} / \mathrm{v})$ methanol/ $50 \mathrm{mM}$ TRIS/glycine, $\mathrm{pH} 8.0$.

Blots were blocked by overnight incubation in $2 \%$ BSA (Fraction V; Sigma, Axel, Belgium) in PBS-Tween-20 (0.1\%) at $4^{\circ} \mathrm{C}$ and 20 -min incubation in $1 \%$ normal goat serum (Amersham International, UK) in PBS-Tween-20 at room temperature. Subsequent- ly, the blots were incubated with a 20 times diluted supernatant of an HNK-1 hybridoma culture for 45 min at room temperature. Alkaline phosphatase-conjugated goat-anti-mouse immunoglobulin IgM F $(\mathrm{ab})_{2}$, (Tago, Burlingame, USA), in a dilution of $1: 10000$ in PBS-Tween-20, was used as second step antibody (incubation $45 \mathrm{~min}$ at room temperature). Between each incubation step, the blots were rinsed five times with $50 \mathrm{ml}$ PBS-Tween-20 (0.1\%). Phosphatases were visualized with a protocol from Blake and coworkers (1984). For control immunoblots we used the medium from the eulture of the HNK-1 hybridoma cells. All other steps were identical. The two-dimensional gel-electrophoresis and the subsequent HNK-1 immunoblotting were performed as previously described (Luider et al. 1992). 

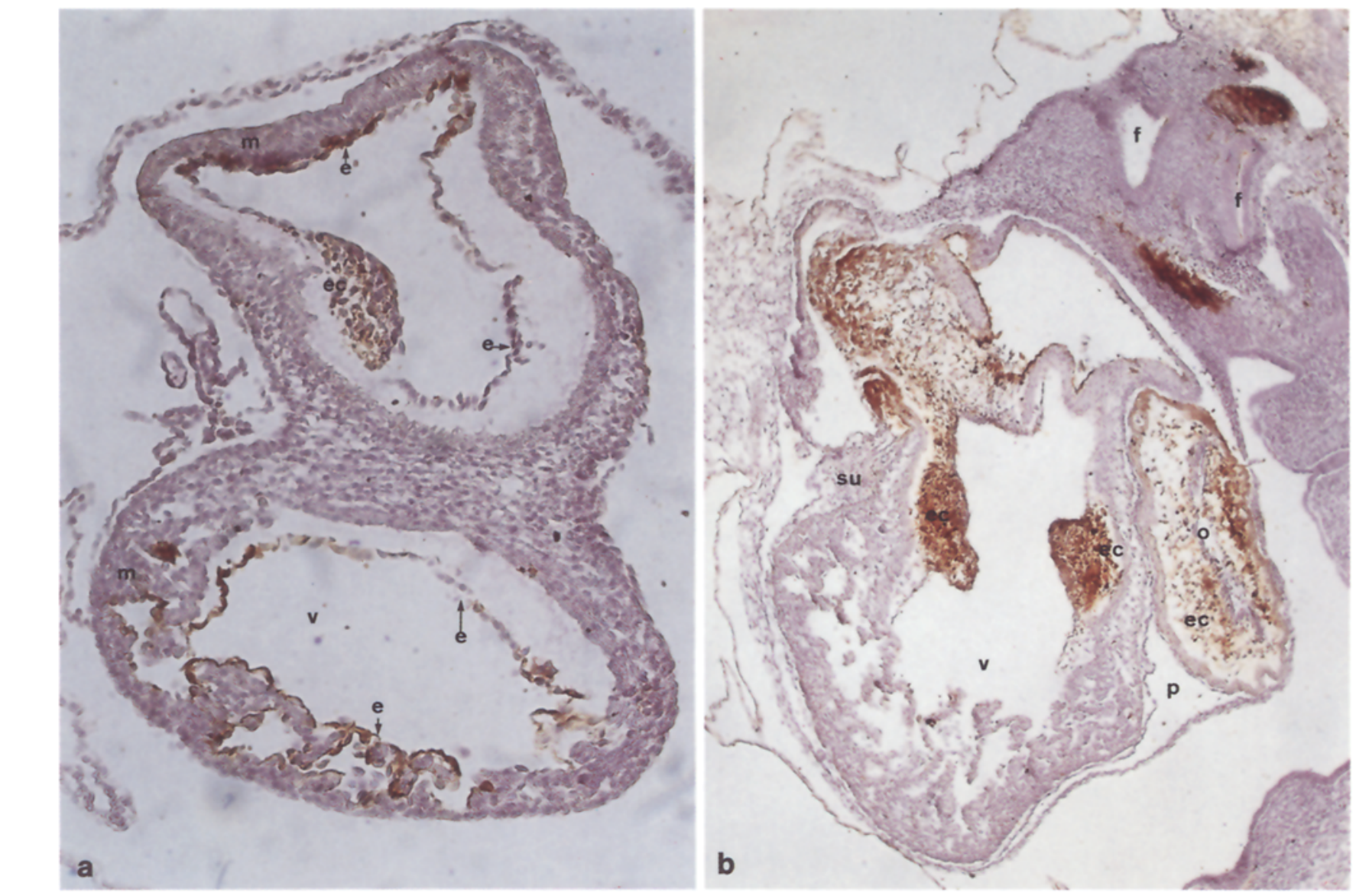

Fig. 2a, b
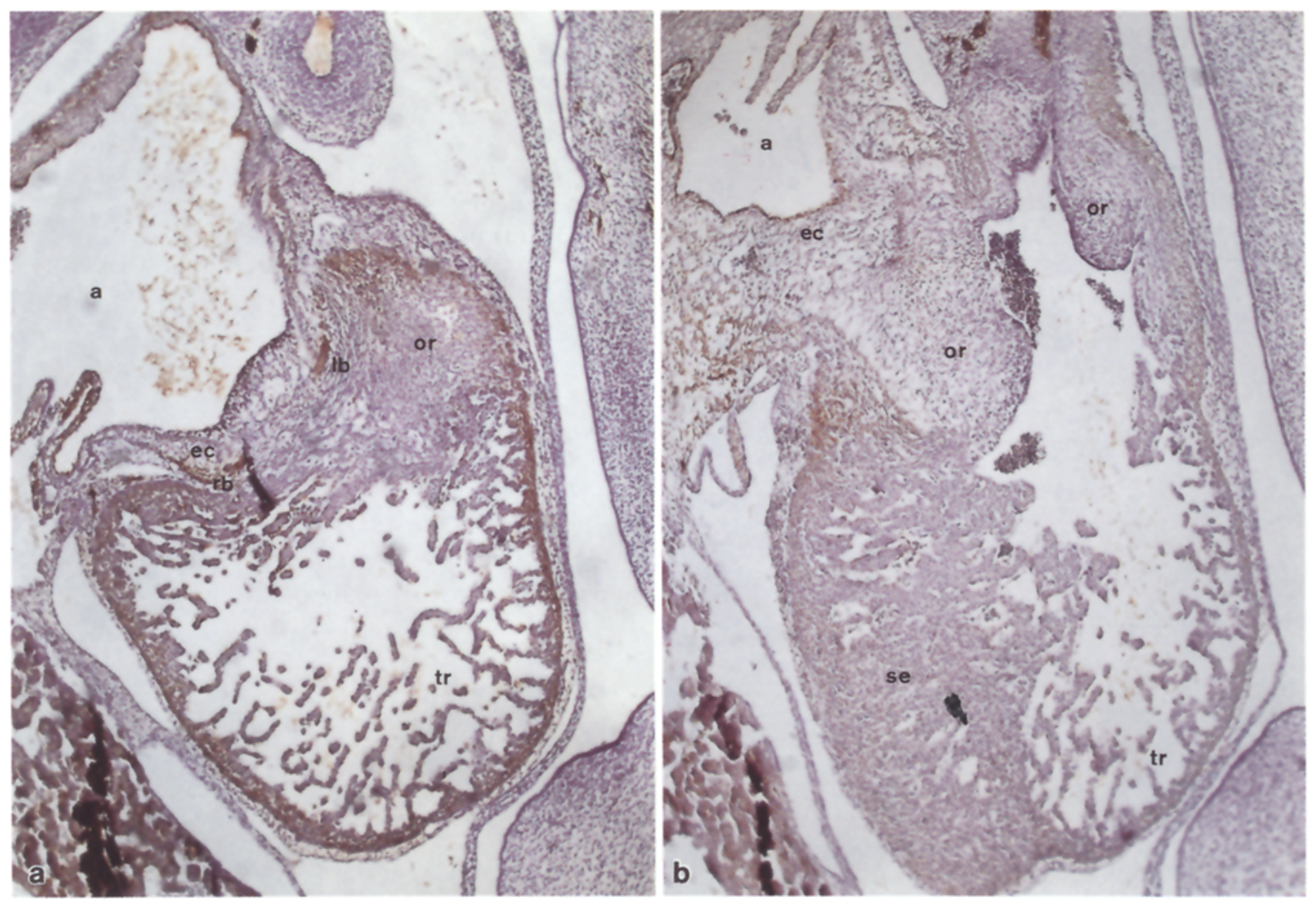


\section{Results}

HNK-1 immunoreactivity in different

developmental stages of the heart

At stage HH 14, HNK-1 immunoreactivity was observed lateral from the dorsal aorta, and in the pharyngeal arch mesenchyme. In the lateral wall of the sinus venosus HNK-1 positivity was observed, but the walls of the primitive atrium, the ventricle and the outflow tract did not contain any HNK-1 labelling (Fig. 1 a). This observation is in agreement with the data of Noden (1991), who found that neural crest cells at stage $\mathrm{HH} 15$ have not yet reached the heart.

At $\mathrm{HH} 17$ through $\mathrm{HH} 21$ the wall of the sinus venosus contained HNK-1-positive cells, and from HH19 onwards the atrioventricular endocardial cushions were labelled with HNK-1 (Fig. 1b, c). In the outflow tract HNK-1 antigens were observed in the cardiac jelly of the cushions and on one side of the myocardium, the inner curvature of the heart tube.

At E3, HNK-1 immunoreactivity is present in the endocardial cushions just below the endocardium. These are seen at the atrioventricular junction and in the outflow tract. At this stage HNK-1-positive endocardial cells were also observed in the endocardium of the primitive ventricle (Fig. 2a).

After E3 the HNK-1 immunoreactivity increased in the heart. Large numbers of HNK-1-positive cells were found in both the atrioventricular and the outflow tract endocardial cushions. At E4 (Fig. 2b) HNK-1 antigens were also observed in the endocardium of the inflow tract region and in the endocardial cushions of the outflow tract. At this stage both the endocardium and myocardium of the ventricle have become HNK-1 negative.

At E5, the immunohistological results were similar to those at E4 and are, therefore not separately shown. The endocardial cushions contained approximately the same quantity of cells per surface unit as at E4, but not every cell was HNK-1 positive. This endocardial staining pattern was also observed at E6.

At E6, HNK-1 positivity was furthermore observed in a narrow band with a diameter of about $50 \mu \mathrm{m}$ in the myocardium of the interventricular septum, extend-

Fig. 2 a, b. HNK-1 immunoreactivity in the endocardial cushions at $\mathrm{E} 3$ (a), and $\mathrm{E} 4$ (b). At E3 HNK-1 expression can also be observed in the endocardium of the ventricle. Note the differences in the staining of the endocardial cells covering the cushions and those related to the myocardium in atrium and ventricle. At E4, additional HNK-1 immunoreactivity can be seen in the inflow tract and in the outflow tract. $e$, endocardial lining; $e c$, endocardial cushions; $f$, foregut pockets; $m$, myocardium; $o$, outflow tract; $p$, pericardial cavity; $s u$, atrioventricular sulcus; $v$, ventricle

Fig. 3a, b. HNK-1 immunoreactivity in sagittal sections through an E6 heart. The compact outer layer of the myocardium of the ventricle and the atrium is HNK-1 immunoreactive (a), whereas in the more lateral section (b), it was HNK-1 negative. $a$, atrium; $t r$, trabeculated myocardium; $e c$, endocardial cushions; $l b$, left bundle branch; or, outflow ridge; $r b$, right bundle branch; se, septum ing to the lateral myocardium (Fig. 3). This staining pattern is only observed at E6; at E8, for instance, the myocardium of the ventricle no longer contains HNK-1 antigens (Fig. 4a).

At E9 the neurons and supportive cells of the subepicardial peripheral nervous system of the heart (including the vagus nerve) have differentiated and bind the HNK1 monoclonal antibody. This is shown in Fig. 4 b, in which the branches of the vagus nerve are clearly labelled at the arterial pole. Furthermore some HNK-1 immunoreactivity was observed in the primordial semilunar valves. The aorticopulmonary septum was labelled with the HNK-1 antibody (not shown).

At E10 the autonomic nerve bundles of the heart and the semilunar as well as the atrioventricular valves contained HNK-1 immunoreactivity. Cardiac conducting cells of the atrioventricular ring were labelled with HNK-1 at the level of the atrioventricular valves, while the endocardium of the atria was also HNK-1 positive.

At E14, the autonomic nerve bundles in the wall of the ventricles were HNK-1 positive (results not shown). Furthermore HNK-1 positivity was observed in the semilunar (Fig. 5) and atrioventricular valves, as well as in the attachment site of the valves. In the valves HNK-1-positive cells were seen, but at the attachment side of the valves the staining was extracellular. The cardiac conducting cells were detected at the level of the atrioventricular valves in the atrioventricular septum (not shown).

In Table 1 we have briefly summarized the immunohistological data. For practical reasons we distinguish four classes of HNK-1-positive structures: (1) structures with contribution of the cardiac neural crest that do not differentiate into neuronal tissue (Class 1); (2) neural crest-derived tissues that differentiate into neuronal tissue (Class 2); (3) tissue structures that are HNK-1 positive before neural crest cells could possibly colonize them (Class 3); (3) tissue structures which are not known to be colonized by cardiac neural crest cells (Class 4). We have determined the neuronal characteristics by morphology, histological topology and the use of neuronspecific antibodies (manuscript in preparation).

\section{$H N K-1$ antigen analysis of different developmental stages of the heart}

In total protein extract of E2 heart, four HNK-1-carrying glycoproteins were visible $(240,100,76,74 \mathrm{kDa})$ at low intensity (Fig. 6; indicated by crosses, respectively). From E4 onwards at least eight major high-molecularmass proteins: $200,200,165,140,120,110,100$, and $80 \times 10^{3}$ were present (indicated by crosses, respectively). Additional HNK-1-positive proteins were present at E4: $206 \mathrm{kD}$, and at $\mathrm{E} 6: 155 \mathrm{kD}$ (indicated by asterisks) coinciding with the strong HNK-1 immunoreactivity in the endocardial cushions and the developing conduction system in the interventricular septum.

We determined whether the eight major HNK-1-positive proteins observed from E4 onwards were plasma 


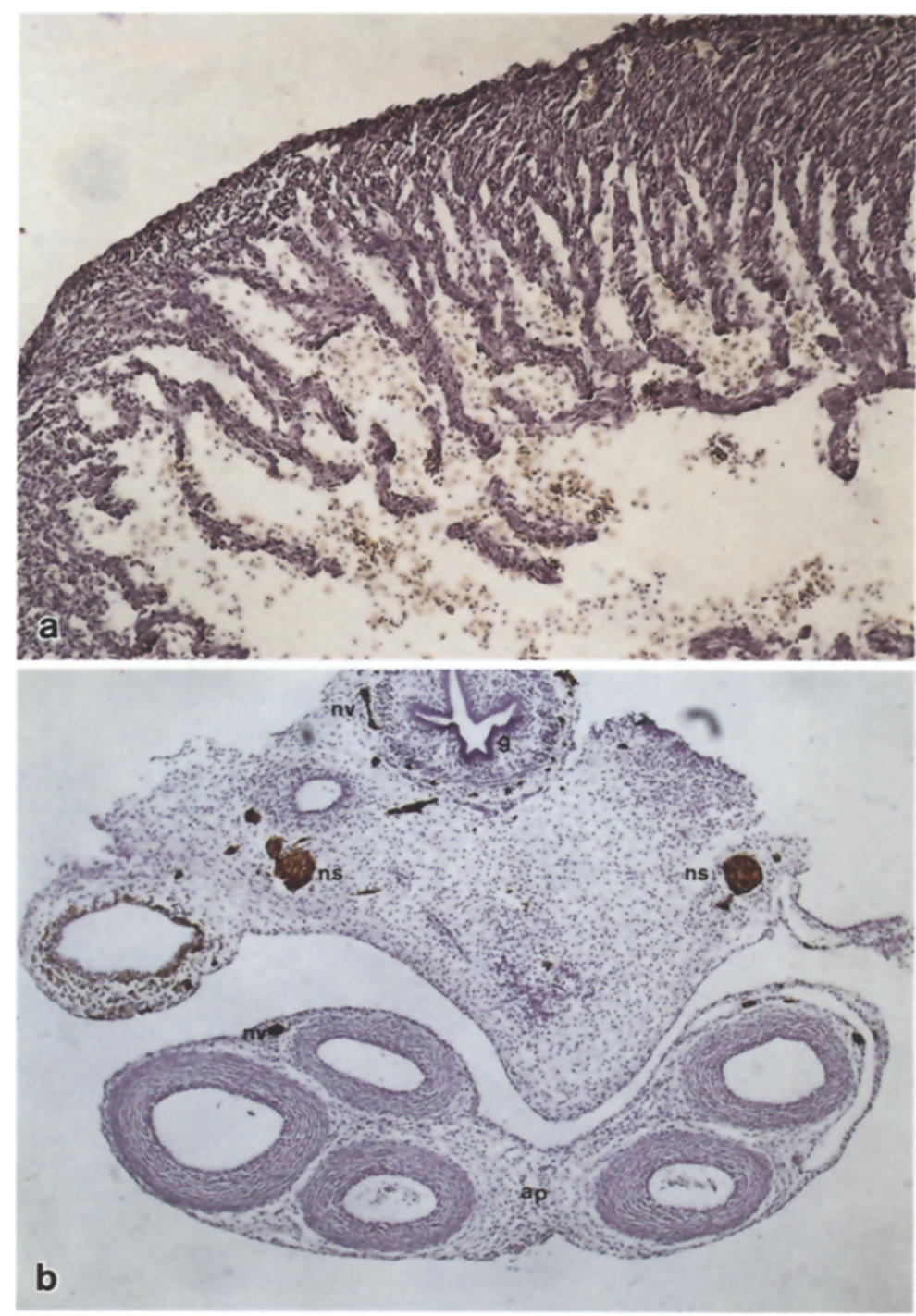

Fig. 4a, b

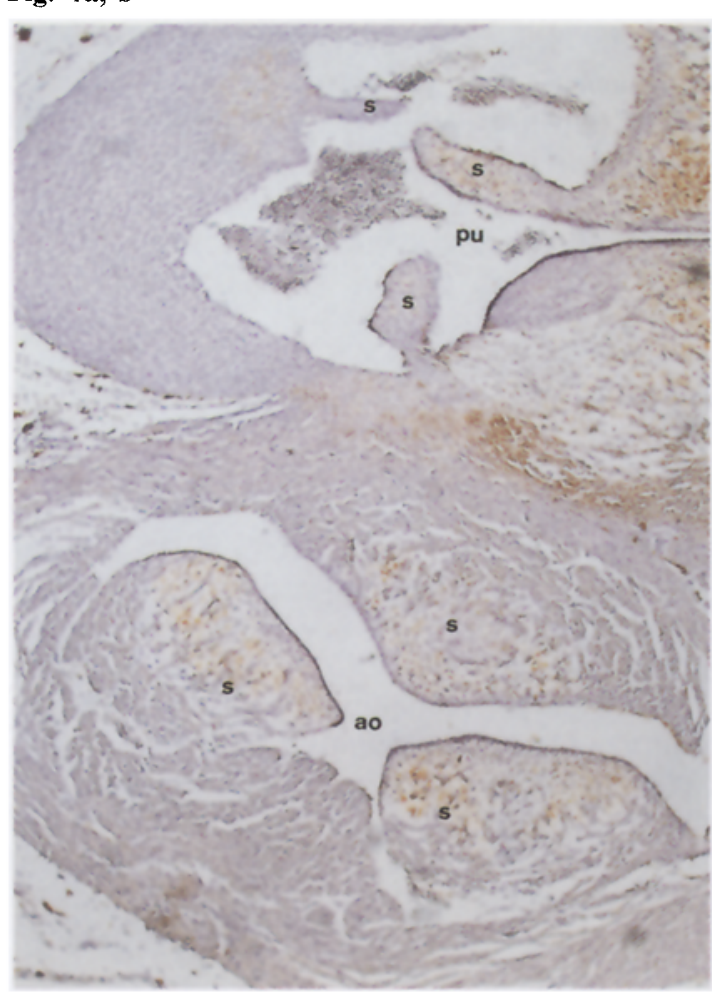

Fig. 4. a Detail of an E8 ventricle. No HNK-1 positivity was observed in the myocardium. b The arterial pole of an E9 embryo. HNK-1-positive branches of the vagus nerve are observed in the connective tissue outside the great arteries. $a p$, arterial pole; $g$, gut; $n v$, vagus nerve; ns, sympathetic chain

Fig. 5. Transverse section through the semilunar valves of an E14 embryo. Three types of HNK-1 expression are observed: (1) HNK-1-positive cells in the valves; (2) reactivity of the extracellular matrix at the attachment of the valves; (3) diffuse labelling of the myocardial cells that will form the developing bundle of His. ao, aorta; $s$, semilunar valves; $p u$, pulmonary artery membrane bound, and compared day E6 with day E9 heart plasma membranes (Fig. 7). Five of the HNK-1carrying proteins from the basic pattern were present in the membrane fraction $(200,165,120,110$, and $80 \mathrm{kD}$; indicated by $1,2,3,4,5$, respectively) and the other three $(240,140,100)$ are not membrane associated. In addition, proteins were observed which specifically co-purify at E6 ( $85 \mathrm{kD}$; indicated as 6) and at E9 $(135 \mathrm{kD}$; indicated as 7). The intensity of the different HNK-1 antigens at these two developmental stages varied considerably.

The pattern of HNK-1-carrying proteins from E4 onwards remained the same in the adult heart. Five of the HNK-1-positive proteins, present during embryonic development of the heart, were also expressed in the adult heart.

Proteins of approximately $200,100,80,65,50$, and $40 \mathrm{kDa}$ (indicated as 1, 2, 3, 4, 5, respectively) were detected on immunoblot of a two-dimensional gel electrophoresis of plasma membranes of adult chicken heart (Fig. 8a). 
Table 1. Spatio-temporal HNK-1 reactivity in diverse embryonic tissue structures

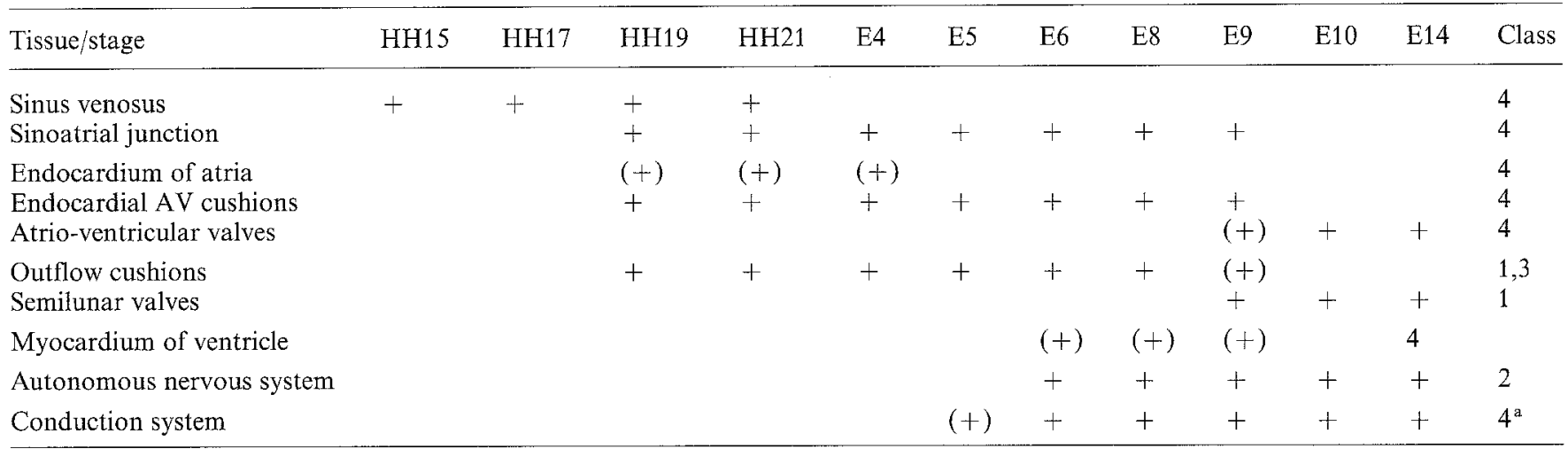

The HNK-1 immunoreactivity is divided into four classes. The first class (1) corresponds to structures that are derived from neural crest cells as determined in quail/chick chimeras, and that do not differentiate into neuronal tissue; the second class (2) corresponds to structures that are neural crest-derived and that differentiate into neuronal tissue; the third class (3) corresponds to tissue sites that are HNK-1 positive before neural crest cells arrive; the fourth class (4) corresponds to $\mathrm{HNK}-1$-positive structures that are not known to be neural crest-derived and that do not correlate with future cardiac neural crest colonization. The absence of a plus sign in the table means either the absence of HNK-1 immunoreactivity or the absence of this specific tissue during a particular stage(s).

a According to Gorza et al. (1988) and Filogamo et al. (1990) this should be classified as 2

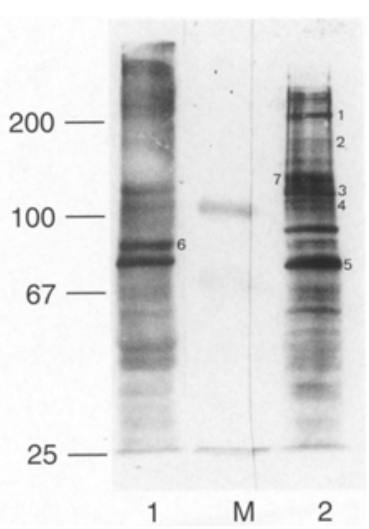

Fig. 7. HNK-1 immunoblot of plasma membranes of the heart of stages E6 (lane 1) and E9 (lane 2). The relative molecular masses are indicated at the left. Control immunoblots showed no bands. The constant pattern of HNK-1 antigens is indicated by $1,2,3$, 4 , and 5. At E6 and E9 two proteins co-purify; they are indicated 6 and 7

part of the outflow ridges, there is no evidence for such a process. Until now it has been assumed that the neural crest cells do not reach the atrioventricular cushions (Kirby et al. 1983).

Our objective was to investigate whether HNK-1-positive cells and HNK-1 antigens are correlated with the homing of neural crest cells in the heart. In a previous study we found that in the developing avian hindgut, HNK-1-positive antigens are present before the arrival of neural crest cells. These $\mathrm{HNK}-1$ antigens are probably involved in the neural crest cell homing of the developing gut (Luider et al. 1992) and clearly show that HNK-1 antigens are not strictly specific for neural crest cells. distal outflow trace endocardial ridges. Although the neural crest cells might also reach the more proximal
In quail/chick chimeras Kirby et al. (1983) and Sumida et al. (1989) described quail cells in the aortic-pulmonary septum as early as stage HH19. Laane and Roest-Wagenaar (1981) and Bartelings and Gittenberger-de Groot (1991 a, b) described for four species the extent of this septum, even below the semilunar valve level into the 

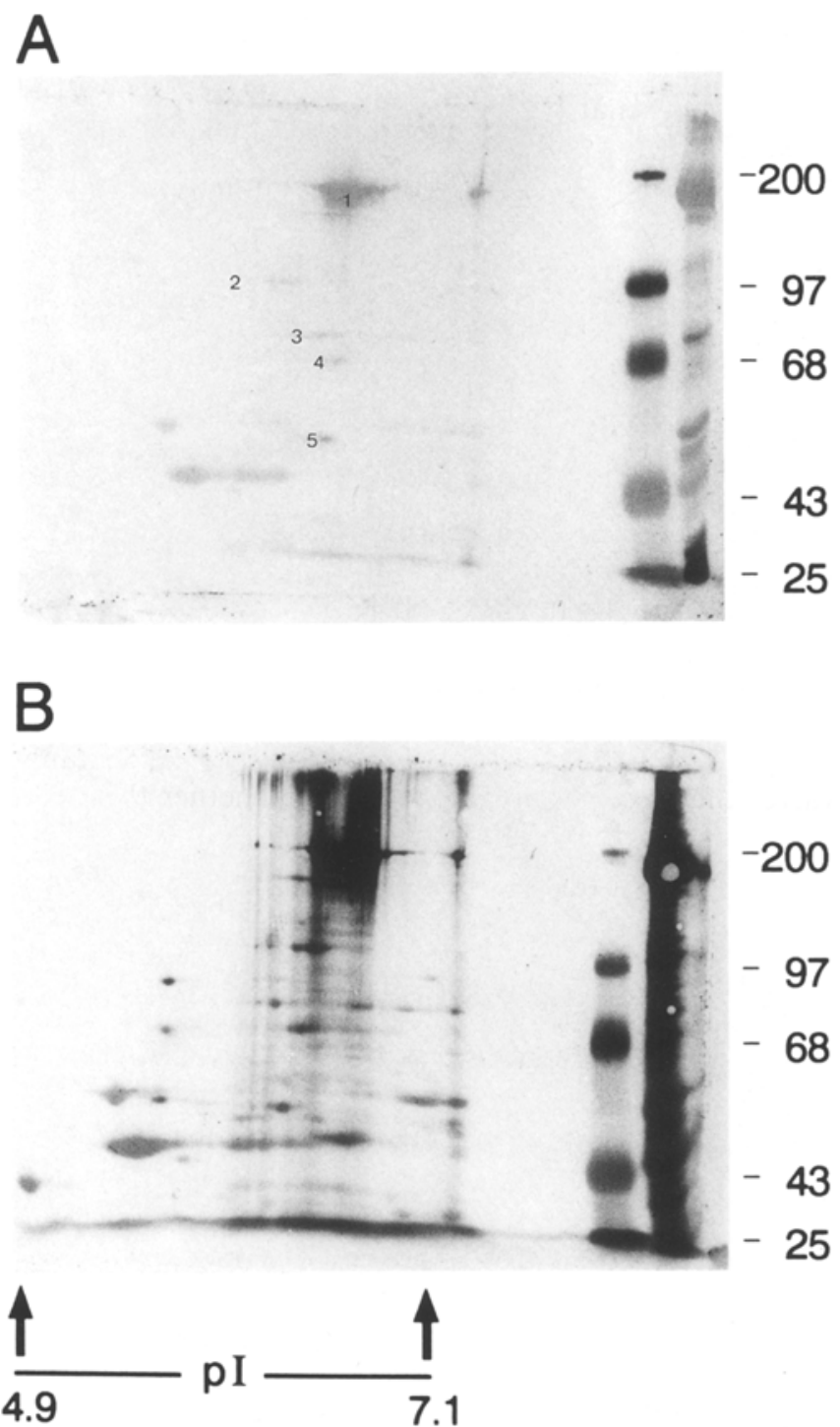

Fig. 8a, b. The 2-D electrophoresis of plasma membranes of adult chicken hearts. Blot labelled with the monoclonal antibody HNK-1 (a), and protein staining with amido black (b). The relative molecular masses are indicated at the right. The basic pattern of HNK-1positive proteins expressed from E6 onwards is indicated with numbers $\left(1=200,2=100,3=80,4=50,5=40 \times 10^{3}\right)$. The isoelectric focusing range was determined by Carbamolyte markers (Pharmacia)

We can relate HNK-1 immunoreactivity in the developing avian heart to the presence of quail neural crest cells in the developing heart of chick quail chimeras, as described in the literature. We found that HNK-1 immunoreactivity is present in the endocardial outflow and atrioventricular cushions (HH 19) before cardiac neural crest cells reach the outflow tract. Noden (1991) determined that neural crest cells reach the level of he outflow tract of the heart at stage HH 17-19 in quail-chick chimeras. In these stages no quail neural crest cells were observed in the AV endocardial cushions. We found that the endocardial cushions as well as their mesenchymal cells in the outflow tract are HNK-1 positive from stages $\mathrm{HH}$ 18-19 onwards, but we cannot determine if this HNK-1 immunoreactivity is due only to the presence of neural crest cells, or originates also from the outflow endocardial cushion mesenchymal cells themselves. We suggest that a very close timing exists between the endogenous HNK-1 expression in the mesenchymal cells of the outflow endocardial cushions and the supposed arrival of HNK-1-positive neural crest cells.

Cardiac neural crest cells are known to migrate towards the heart from the pharyngeal arch arteries into the aortic sac down to approximately the semilunar valve level. It still remains to be confirmed whether other segments of the heart, such as the proximal part of the outflow ridges and atrio-ventricular cushions, contain substantial quantities of neural crest-derived cells. We observed that the expression of HNK-1 antigens started first in the sinus venosus. Later it was present in the endocardial cushions of both the atrioventricular canal and outflow tract. As there is no evidence that neural crest cells colonize other parts of the heart, the assumption that HNK-1 antigens function as a scaffold for migrating cardiac neural crest cells has still to be substantiated.

\section{Discrimination of four classes of HNK-1 immunoreactivity}

We distinguished four classes of HNK-1 immunoreactivity during heart development. The first includes HNK-1 immunoreactivity present in structures that are known from ablation and chimaera experiments to be related to the neural crest (Kirby 1989; Sumida et al. 1989; Noden 1991), but which do not differentiate into neurons. We observed HNK-1-positive staining in the following neural crest-related tissues: the primordia of the semilunar valve leaflets, the aorticopulmonary septum, and possibly in the distal part of the outflow tract cushions.

The second class of HNK-1 immunoreactivity is that found in neural crest-related cells that have differentiated into neuronal cells. HNK-1 antigens were observed in the sympathetic ganglia from E9 onwards. Kirby and Stewart (1983) have shown that in quail/chick chimeras the cardiac ganglia originate from neural crest adjacent to somites $1-3$, although the nodose placode is also involved in the formation of the autonomous innervation of the heart). At E7 they observed clusters of quail cells that later become the cardiac ganglia, and at E9 these ganglia were formed.

The third class of HNK-1 immunoreactivity is present at sites that are possibly colonized by neural crest cells. We observed that the outflow endocardial cushions are HNK-1 positive before cardiac neural crest cells are supposed to reach these structures.

The fourth class of HNK-1 immunoreactivity is to our knowledge not related to neural crest cells, neural crest derivatives, or their future endocardial or myocardial binding sites. At stage HH 15 through 21, we observed HNK-1-positive cells in the wall of the sinus venosus, which is not related to the neural crest, as shown by chimera experiments and other tracing techniques. At E3 the endocardium is HNK-1 positive. This tissue does not contain quail neural crest cells in quail/chick 
chimeras (Kirby and Stewart 1983; Noden 1991). Endocardial cells share an important characteristic with neural crest cells, in that both cells can transform into mesenchymal cells with migrating capacities (Noden 1991; Crossin and Hoffman 1991).

At E6 we observed a narrow band of HNK-1 immunoreactivity in the myocardium of the ventricle, and then at E8 this HNK-1-positive band was observed at the atrioventricular junction. The HNK-1 antibodies label the atrioventricular bundle from the level of the atrioventricular valves to halfway along the interventricular spectum. It has been suggested that the specialized cardiac muscle cells of the conduction system originate from mesodermic precursors (Viragh and Challice 1983). The primordium of the bundle of His and its branches, including the Purkinje fibres, are thought to originate from myocytes, and to develop in the bulboventricular ring of the primitive heart tube (Davies et al. 1983). However, a few investigators (Gorza et al. 1988; Filogamo et al. 1990) claim that cardiac conducting cells originate from the neural crest.

From E10 onwards the myocardial cells express HNK-1, and at E14 HNK-1 antigens are observed in the extracellular matrix of the myocardial base of all valves. The valves contain tenascin (Garcia-Martinez et al. 1990), which is a HNK-1-containing extracellular matrix molecule. The relative molecular masses of chick tenascin subunits have been calculated from the amino acid sequences to be 280,200 , and $170 \mathrm{kDa}$ (ChiquetErismann 1990). We observed HNK-1-carrying proteins at 200 and $165 \mathrm{kDa}$ on immunoblot. So, the immunohistochemical staining pattern we observe in the myocardial base of the valves could very well reflect tenascin, providing a good environment for migrating cells (ChiquetErismann 1990).

\section{Characterization of $H N K-1$ antigens}

The results of immunoblots, and those of immunostained sections can be correlated. At E2 a few HNK-1bearing proteins were present on immunoblot. The immunostained sections at stage HH $15(\sim \mathrm{E} 2)$ were HNK1 negative in the heart, except for the sinus venosus. From E4 onwards, there was a more complex pattern of HNK-1 antigens, changing considerably until E6, when HNK-1 positivity was observed in the myocardium of the ventricle in the immunostained sections, while an additional $155 \mathrm{kDa}$ protein was present on immunoblot. After E6, a more or less constant composition of HNK-1 antigens was observed both on the immunostained sections and on the immunoblot.

From HH15 to HH17 no HNK-1 labelling was observed in the outflow tract cushion of the heart. Tenascin, an extracellular adhesion molecule in the cardiac jelly, known to carry the HNK-1 epitope, was not detected by the HNK-1 monoclonal antibody. The outflow tract strongly reacted with the M1B4 monoclonal antibody, an antibody specific for tenascin (Chiquet and Fambrough 1984). In this case, the cardiac isoforms of tenascin are apparently HNK-1 negative.

\section{HNK-1-positive morphological dynamic regions}

We conclude that both neural crest-related and non-related HNK-1 antigens are present in the developing heart. In general, the HNK-1 immunoreactivity is especially seen in morphologically active regions, those which are subject to re-ordering of tissue in a relatively short period. Examples of such morphologically dynamic regions are the endocardial lining, the endocardial cushions, the developing conduction system and the aortico-pulmonary septum. The various HNK-1 antigens consist of a series of glycoproteins changing in a stagedependent manner, sometimes corresponding to immunohistological changes. We observed a correlation between the future sites of neural crest cell localization and the presence of HNK-1-positive antigens. These HNK-1 antigens may function as target molecules in the various parts of the heart. The outflow tract cushions are possible candidates, because they are situated in the neighbourhood of the aortic sac and the semilunar valves that receive neural crest cells. Whether the atrioventricular endocardial cushions eventually also receive neural crest cells remains to be elucidated.

Acknowledgements. We thank Prof. A.C. Gittenberger-de Groot for critical reading of the manuscript and for helpful discussion, and Mr. T. de Vries Lentsch for photography.

\section{References}

Abo T, Balch CM (1981) A differentiation antigen of human NK and $\mathrm{K}$ cells identified by a monoclonal antibody HNK-1. J Immunol 127: 1024-1029

Argüello C, Alanis J, Valenzuela B (1988) The early development of the atrioventricular node and the bundle of His in the embryonic chick heart. An electrophysiological and morphological study. Development 102:623-637

Bartelings MM, Gittenberger-de Groot AC (1991 a) Morphologenetic considerations on congenital malformations of the outflow tract. Part 1: Common arterial trunk and tetralogy of Fallot. Int J Cardiol 32:213-230

Bartelings MM, Gittenberger-de Groot AC (1991 b) Morphogenetic considerations on congenital malformations of the outflow tract. Part 2: Complete transposition of the great arteries and doublet outlet right ventricle. Int J Cardiol 33:5-26

Bockman DE, Redmond ME, Waldo KL, Davis H, Kirby ME (1987) Effect of neural crest ablation on development of the heart and arch arteries in the chick. Am J Anat 180:332-341

Blake MS, Johnston KH, Russel-Jones GJ, Gotschlich EC (1984) A rapid and sensitive method for detection of alkaline phosphatase. Anal Biochem 136:175-179

Bronner-Fraser M (1987) Perturbation of cranial neural crest migration by the HNK-1 antibody. Dev Biol 123:321-331

Canning DR, Stern CD (1988) Changes in the expression of the carbohydrate epitope HNK-1 associated with mesoderm induction in the chick embryo. Development 104:643-655

Chiquet R, Fambrough DM (1984) Chick myotendinous antigen. II. A novel extracellular glycoprotein complex consisting of large disulfide-linked subunits. J Cell Biol 98:1937-1946

Chiquet-Erismann R (1990) What distinguishes tenascin from fibronectin? FASEB J 4:2598-2640

Crossin KL, Hoffman S (1991) Expression of adhesion molecules during formation and differentiation of the avian endocardial cushion tissue. Dev Biol 145:277-286

Davies MJ, Anderson RH, Becker AE (1983) Embryology of the conduction tissues. In: Davies MJ, Anderson RH, Becker AE 
(eds) The conduction system of the heart. Butterworth, London, pp 81-94

Faissner A (1987) Monoclonal antibody detects carbohydrate microheterogeneity on the murine cell adhesion molecule L1. Neurosci Lett $83: 327-332$

Filogamo G, Corvetti G, Daneo LS (1990) Differentiation of cardiac conducting cells from the neural crest. J Auton Nerv Syst 30:S55-S58

Garcia-Martinez V, Sanchez-Quintana D, Hurle JM (1990) Histogenesis of the semilunar valves: an immunohistochemical analysis of tenascin and type-I collagen distribution in developing chick heart valves. Cell Tissue Res 259:299-304

Gorza L, Schiaffiuno S, Vitadello M (1988) Heart conduction system: a neural crest derivative? Brain Res 457:360-366

Hamburger V, Hamilton HL (1951) A series of normal stages in the development of the chick embryo. J Morphol 88:49-67

Hoffman S, Edelman GM (1987) A proteoglycan with HNK-1 antigenic determinants is a neuron-associated ligand for cytotactin. Proc Natl Acad Sci USA 84:2523-2527

Keilhauer G, Faissner A, Schachner M (1985) Differential inhibition of neuron-neuron, neuron-astrocyte and astrocyte-astrocyte adhesion by L1, L2, and N-CAM antibodies. Nature 316:728-730

Kirby ML (1989) Plasticity and predetermination of mesencephalic and trunk neural crest transplanted into the region of the cardiac neural crest. Dev Biol 134:402-412

Kirby ML, Stewart DE (1983) Neural crest origin of cardiac ganglion cells in the chick embryo: identification and extirpation. Dev Biol 97:433-443

Kirby ML, Gale TF, Steward DE (1983) Neural crest cells contribute to normal aorticopulmonary septation. Science 220:10591061

Kirby ME, Waldo KL (1990) Role of neural crest in congenital heart disease. Circulation 82:332-340

Kruse J, Mailhammer R, Wernecke H, Faissner A, Sommer I, Gorides C, Schachner M (1984) Neural cell adhesion molecules and myelin-associated glycoprotein share a common carbohydrate moiety recognized by monoclonal antibodies $\mathrm{L} 2$ and HNK-1. Nature 311:153-155

Künemund V, Jungalwala FB, Fisher G, Chou DKH, Keilhauer G, Schachner M (1988) The L2/HNK-1 carbohydrate of neural cell adhesion molecules is involved in cell interactions. J Cell Biol 106:213-223

Laane HM, Roest-Wagenaar JA (1981) Development and fusion of endocardial structures in the arterial pole of the heart of chick, rat, and human embryos. In: Pexieder T (ed) Mechanism of cardiac morphogenesis and teratogenesis. Perspectives of cardial-vascular research. Raven Press, New York, pp 267-277

LeDouarin NM (1982) The neural crest. Cambridge University Press, Cambridge

LeLièvre CS, LeDouarin NM (1975) Mesenchymal derivatives of the neural crest: analysis of chimeric quail and chick embryos. J Embryol Exp Morphol 34:125-154
Luider TM, Peters-van der Sanden MJH, Molenaar JC, Tibboel D, van der Kamp AWM, Meijers C (1992) Characterization of HNK-1 antigens during the formation of the avian enteric nervous system. Development 115:561-572

Maeda T, Balakrishnan K, Mehdi SQ (1983) A simple and rapid method for the preparation of plasma membranes. Biochim Biophys Acta 731:115-120

Marino TA, Truex RC, Marino DR (1979) The development of the atrioventricular node and bundle in ferret heart. Am J Anat 154:135-150

Markwald RR, Fitzharris TP, Maniasek FJ (1977) Structural development of endocardial cushions. Am J Anat 148:85-119

Markwald RR, Mjaatvedt CH, Krug EL (1990) Inductive interactions in heart development. In: Bockman D, Kirby ML (eds) Embryonic origins of defective heart development. NY Acad Sci, New York, pp 13-25

Noden DM (1991) Origins and patterning of avian outflow tract endocardium. Development 111:867-876

Pesheva P, Horowitz AF, Schachner M (1987) Integrin, the cell surface receptor for fibronectin and laminin, expresses the L2/ HNK-1 and L3 carbohydrate structures shared by adhesion molecules. Neurosci Lett 83:303-306

Phillips MT, Kirby ML, Forbes G (1987) Analysis of cranial neural crest distribution in the developing heart using chick quail chimeras. Circ Res 60:27-30

De Ruiter MC, Poelmann RE, Van der Plas-de Vries I, Mentink MMT, Gittenberger-de Groot AC (1992) The development of the myocardium and endocardium in mouse embryos. Fusion of two heart tubes? Anat Embryol 185:461-473

Sulik KK, Cook CS, Webster WS (1988) Teratogens and craniofacial malformations: relationship to cell death. Development S103:213-230

Sumida H, Akimoto N, Nakamura H (1989) Distribution of the neural crest cells in the heart of birds: a three dimensional analysis. Anat Embryol 180:29-35

Tucker GC, Aoyama H, Lipinski M, Tursz T, Thiery JP (1984) Identical reactivity of monoclonal antibodies HNK-1 and NC-1 conservation in vertebrates on cells derived from the neural primordium and on some leucocytes. Cell Differ 14:223-230

Tucker GC, Ciment G, Thiery JP (1986) Pathways of avian neural crest cell migration in the developing gut. Dev Biol 116:439-450

Vincent M, Duband J-L, Thiery JP (1983) A cell surface determinant expressed early on migrating avian neural crest cells. Dev Brain Res 9:235-238

Virágh S, Challice CE (1983) The development of the early atrioventricular conduction system in the embryonic heart. Can J Physiol Pharmacol 61:775-792

Wenink ACG (1976) Development of the human cardiac conducting system. J Anat 121:617-631

Wenink ACG, Gittenberger-de Groot AC (1985) The role of atrioventricular endocardial cushions in the septation of the heart. Int J Cardiol 8:25-44 